\title{
Austrian versus Hungarian bauxites in an Alpine tectonic context: a tribute to Prof. Andrea MindszenTy
}

\author{
TARI, Gábor ${ }^{1}$, LiNZER, Hans-Gert² \\ 'OMV, Trabrennstrasse 6-8.1020 Vienna, Austria, gabor.tari@omv.com \\ ${ }^{2} \mathrm{RAG}$, Schwarzenbergplatz 16. 1015 Vienna, Austria
}

\section{Osztrák és magyar bauxitok egy alpi tektonikai keretben: tisztelet MINDSZENTY Andrea professzornak}

Összefoglalás

A kréta korú osztrák-magyar bauxitok részletes korrelációját MinDSZENTY Andrea tette közzé elsőként a 1980-as években. Az Északi-Mészkőalpokban és a Dunántúli-középhegységben elhelyezkedő bauxitok közötti jelenlegi távolság néhány száz kilométer nagyságrendú. A késő-krétára (turontól a kora-santoniig) vonatkozó vázlatos palinspasztikus rekonstrukció azonban sokkal közelebbi egykori helyzetükre utal. Ugyanakkor, fontos különbségek is vannak ezeknek a bauxitoknak a tulajdonságai között, amelyek a felszínre került kora-alpi takarórenszer fölötti eltérő paleogeográfiai helyzetüket tükrözik. Más jellegú eltérések, mint például a porozitásban mutatkozó különbségek, a későbbi alpi szerkezeti felülbélyegzésnek tudhatók be.

Az osztrák és magyar bauxitok nemcsak a képződésükkel egyidős földtani viszonyokról nyújtanak információkat, hanem a regionális geodinamikai környezetre vonatkozó adatokkal is szolgálnak közvetlenül a lerakódásuk előtt és után is.

A kréta bauxitok tipikus lerakódási környezete a tágabb alpi régióban különféle flexurális medencék peremén végbement kiemelkedéssel és karsztosodással függött össze. A bauxitok fontos földtani információkkal szolgálhatnak az egykori regionális geodinamikai folyamatokról, ahogy erre MiNDSZENTY Andrea úttörő módon már az 1990-es évek elején rámutatott.

Tárgyszavak: bauxit, kréta, flexurális medence, alpi, Ausztria, Magyarország

Abstract

The correlation between the respective Cretaceous bauxites of Austria and Hungary was first highlighted by the pioneering work of Andrea MINDSZENTY in the 1980s. The physical distance today between these bauxite occurrences, located in the Northern Calcareous Alps (Austria) and the Transdanubian Range (Hungary), is on the order of one hundred kilometres. However, a semi-quantitative palinspastic reconstruction of their relative positions at the time of the bauxite deposition during the Late Cretaceous (Turonian to early Santonian) indicates their proximity. The important differences between these Upper Cretaceous bauxites are due to their different palaeogeographic settings during their deposition on a subaerially exposed Eo-Alpine nappe substratum. Some other differences, such as porosity, can be attributed to the subsequent tectonic overprint in the Alpine edifice.

The Austrian and Hungarian bauxites not only provide important information about the syn-depositional geological landscape but also carry clues about the pre- and post-depositional regional tectonic context of the areas where they developed.

The typical setting for many of the Cretaceous bauxites in the broader Alpine region was uplift and karstification, in association with the formation of various flexural basin systems. Therefore bauxites, in general, may contain important geological information about the regional geodynamic processes. The latter point was made by Andrea MiNDSZENTY, in a pioneering manner, in the early 1990s.

Keywords: bauxite, Cretaceous, flexural basin, Alpine, Austria, Hungary

\section{Introduction}

The first systematic comparison of the Austrian and Hungarian bauxites of the Northern Calcareous Alps (NCA) and the Transdanubian Range (TR), respectively (Figure 1), were published by MindSZENTY et al. (1987, 1991) and D'ARGENio \& MindsZENTy (1987). Whereas in both areas there were numerous studies dedicated to the bauxites 

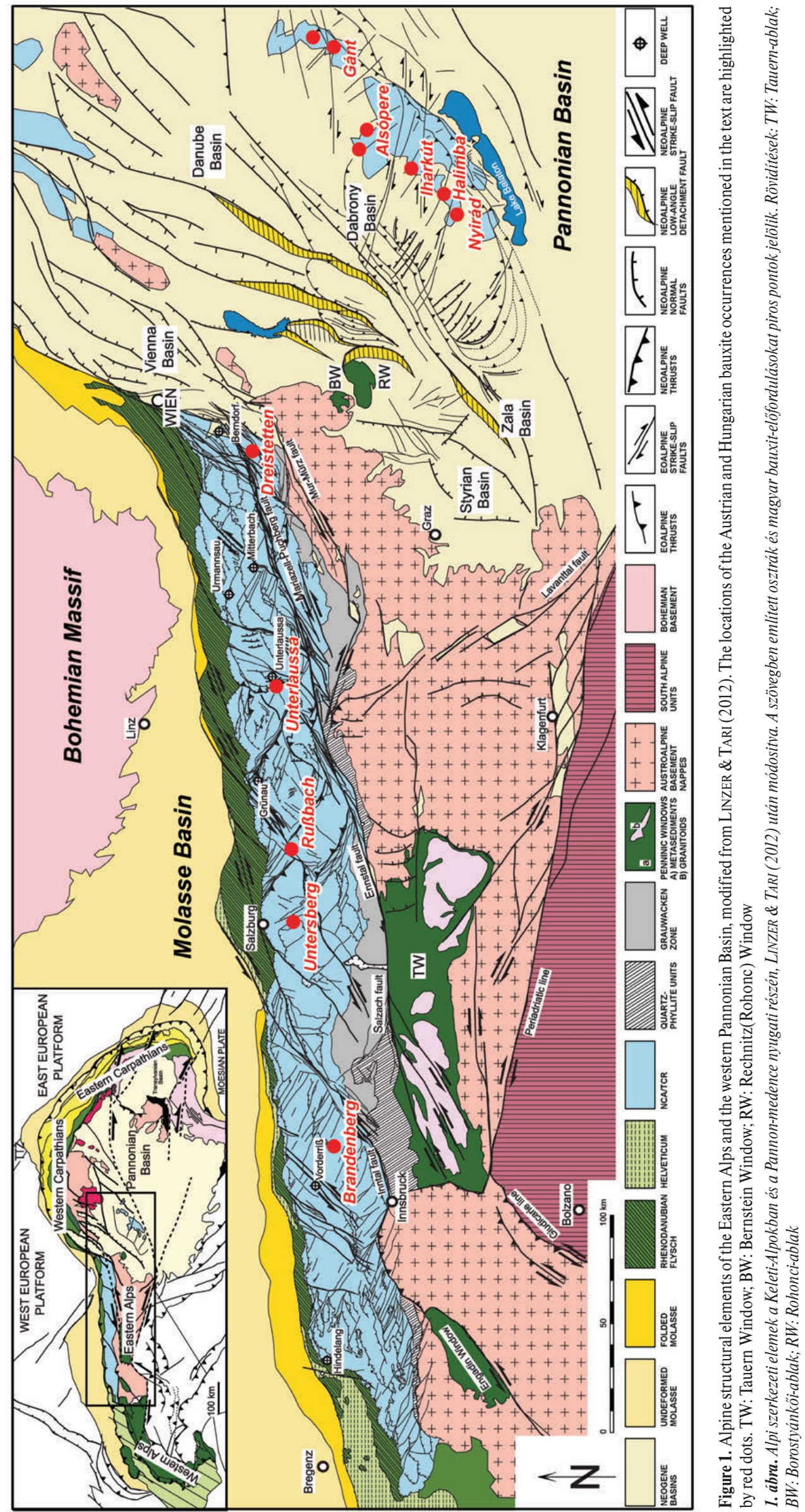
themselves (e.g. MindsZENTY et al. 1991, BÁRDOSSY \& MindSZENTY 2013) the attempt to directly correlate and compare these Austrian and Hungarian deposits was an important first attempt.

Since then, many more studies were devoted to the understanding of the geodynamic context of the deposition of Cretaceous bauxites in the broader area of the Alps and the Mediterranean (D'ARgenio \& Mindszenty 1987, MindSZENTY et al. 1987, 1995, 2000; D'ARGENIO \& MindSZENTY 1995).

More than two decades after these pioneering publications, the present paper aims to a) emphasize the significance and longevity of the observations and interpretations made by Prof. Andrea MindsZENTY, b) to briefly overview the progress made in the understanding of the regional Alpine structural evolution as it relates to bauxite formation and c) to highlight the need to continue the studies of bauxites with modern techniques as they contain valuable geologic information about regional-scale Alpine geodynamic processes.

\section{Cretaceous bauxite occurrences in Austria and Hungary}

The bauxite deposites in Austria are distributed in an $\mathrm{W}-$ E direction along the NCA (Figure 1), the most important ones being Brandenberg in Tirol, Untersberg near Salzburg, Rußbach-Almweg near Strobl, Unterlaussa near Windischgarsten and Dreistetten, west of Wiener Neustadt (e.g. SCHADLER 1950, HABERFELNER 1951, RUTTNER \& WOLETZ 1957, PlÖChINGER 1960, SCHUlz 1960, RutTNER 1970, 1987, GÜNTHER \& TiCHY 1978, LEISs 1989, MindSZENTY et al. 2005). The stratigraphic position and age of all these bauxite occurrences are quite uniform (Figure 2) at the base of the Lower Gosau Subgroup (sensu WAGREICH \& FAUPL 1994) corresponding to a Turonian to Coniacian depositional period. The bauxites deposited on a major regional Eo-Alpine unconformity called "pre-Gosau", as the nappe stacking and folding corresponding to this unconformity predates the deposition of the much less deformed Upper Cretaceous Gosau beds (e.g. Mindszenty et al. 1987). The main lithological characteristics of the Austrian bauxites have been summarized in details by MiNDSZENTY et al. (1987) and therefore they will not be repeated here.

The Hungarian bauxites of the TR are occupying a relatively smaller area but with many more occurrences than in Austria (Figure 1). The most important locations, most of them actually corresponding to former industrial bauxite mining sites, are: Nyirád, Halimba, Iharkút, Fenyőfó, Alsópere, Bakonyoszlop, Iszkaszentgyörgy, Gánt and Nagyegyháza. The amount of geological literature describing the Hungarian bauxites is at least an order of magnitude larger than the corresponding Austrian one. This is primarily due to the intensive industrial exploration and exploitation of Hungarian bauxite deposits during the second half of the twentieth century. Obviously, the fact that Hungarian bauxites occur at three distinct stratigraphic levels (Albian, early Senonian, early Eocene), whereas Austrian bauxites were described only from Upper Cretaceous strata so far (Figure 2), also explains the striking inequality in the numbers of bauxite-related scientific publications. It is to be noted that bauxite was even resedimented from the various levels into a Miocene red clay formation in the TR (KELEMEN et al. 2017).

As to the relation of the multiple bauxite horizons within the TR (Figure 2) to the regional Alpine structure and palaeogeography, MindszenTy (1984) published an outstanding summary cartoon (Figure 3). In idealized transects she showed the major stages of bauxite accumulation in the $\mathrm{TR}$, corresponding to certain periods in the Alpine evolution of the region.

During the Albian, bauxite was depositing in the subaerially exposed flanks of the early, gentle major synclines of the TR formed during the "Austrian" phase of Eo-Alpine shortening (Figure 3a). Karstification has not reached the Upper Triassic Main Dolomite beneath Lower Cretaceous to Uppermost Triassic limestones and bauxite was accumulating under "vadose" and freatic conditions based on the textural signature of the Alsópere deposit. As Upper Albian to Cenomanian sediments gradually onlapped the flanks of the synclines, the loci of bauxite deposition shifted updip (Figure 3a).

After the "pre-Gosau" Eo-Alpine deformational phase the entire region of the TR had experienced surface uplift and denudation (Figure $3 b$ ). The associated erosion removed large part of the pre-existing Mesozoic sequence, locally even the Albian-covered bauxite itself reworking it into new accumulations. Erosion reached not only the Norian Main Dolomite, but even the Carnian Veszprém Marl has been subaerially exposed based on the dolomitic and siliciclastic extraclasts in the Senonian-covered bauxite. Bauxite deposition occurred in a saturated facies close to the shoreline at low elevation and in a vadose environment on the higher parts of the karstified terrain (Figure $3 b$ ).

Finally, following the "Laramian" Eo-Alpine deformational phase (Figure 2), redeposition of existing vadose bauxites must have contributed significantly to the youngest, Palaeocene to Lower Eocene bauxites (Figure 3c). These sediments accumulated on top of the Campanian Ugod Limestone Formation partly in a saturated facies. Due to the overall transgressive character of the immediately overlying Middle Eocene sequence, most of the saturated and vadose/freatic bauxites were preserved (Figure 3c).

\section{Differences between the Austrian and Hungarian bauxites}

Since there are no documentations of age equivalent Palaeocene/Eocene or Lower Cretaceous bauxites or resedimented bauxite-bearing Miocene red clays in Austria to date (Figure 1), the discussion below concerns only with the Upper Cretaceous bauxites. The overall similarities and 


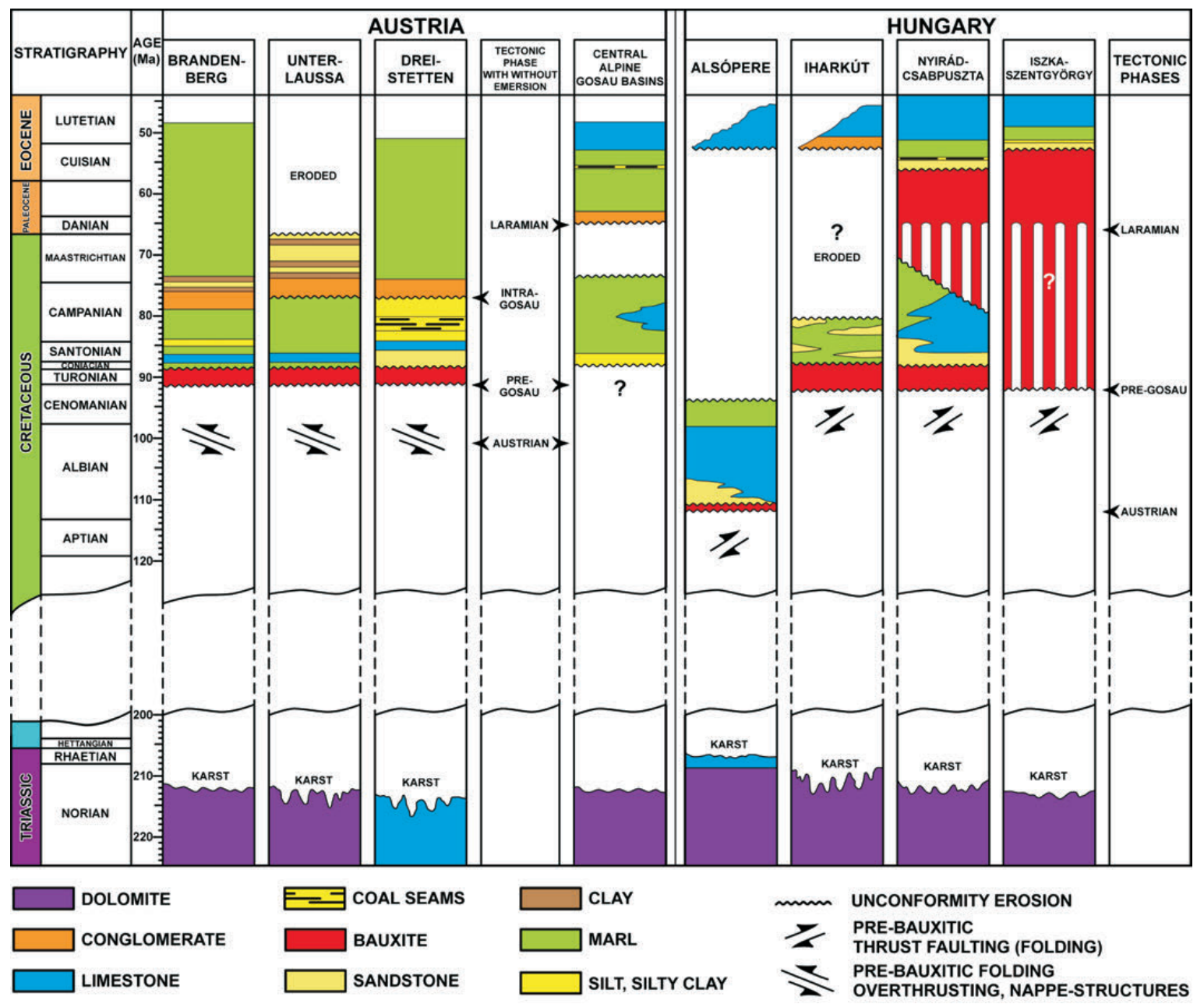

Figure 2. Stratigraphic position of the Austrian and Hungarian bauxites, reproduced from MiNDSZENTY et al. (1987). For the locations of these occurrences see Figure 1.

2. ábra. Az osztrák és magyar bauxitok rétegtani helyzete MINDSZENTY et al. (1987) után módositva

differences between the Austrian and Hungarian bauxites were summarized by MINDSZENTY et al. (1987). Here only some of the differences are highlighted, which may reflect differences in the regional-scale tectonic settings of these bauxites:

a) The Senonian cover above the bauxites (Figure 2) is thicker in Austria, up to a few kilometres locally, corresponding to pronounced subsidence (e.g. WAGREICH 1988, 1995) as opposed to the no more than $1000 \mathrm{~m}$ thick cover in Hungary which deposited due relatively slow, gradual subsidence (e.g. HAAS 1983, SIEGL-FARKAS \& HAAS 2002).

b) Overall, the typical Gosau-type facies succession in Austria has coarse continental clastics filling a pre-existing erosional relief above an erosional unconformity corresponding to the pre-Gosau deformational phase. The shallow marine mixed carbonates and siliciclastics of the Turonian to Coniacian Lower Gosau Subgroup (sensu WAGREICH \& FAUPL 1994) overlying the conglomerates are more evenly distributed but do reflect deposition in subbasins. The Upper Gosau Subgroup is dominated by Santonian to Eocene age deepwater turbiditic sediments, in part deposited below the carbonate compensation depth (CCD). In contrast, the lateral lithofacies variations are more predictable in the Senonian of the TR, indicating deposition in a single basin where the intitial inherited palaeotopography had a major control on the sedimentation (e.g. HAAS 1999). Furthermore, the gradual subsidence in the Senonian basin of the TR did not result in a deep basin reaching the CCD.

c) Post-accumulation chemical alteration of bauxites is minor in Austria versus medium to intense in Hungary.

d) Degree of compaction is significantly higher (porosity: 6-23\%) in Austria compared to the low to medium compaction in Hungary (25-43\%).

e) Chromite is quite frequent in the Austrian bauxit deposits, however, it is not so prevalent in the bauxites of the TR in Hungary (ÁRGYELÁn \& HoRVÁTH 2002).

f) Some special minerals, such as the radioactive carnotite (a potassium uranium vanadate) reported from the Unterlaussa bauxite deposit (KÖHLER 1955), appears to be missing in the TR bauxites (Sándor SzAKÁLL, personal communication 2017).

All these observations need to be addressed in a regional palaeogeographic model which could explain the differences between the Upper Cretaceous Austrian and Hungarian bauxites. 


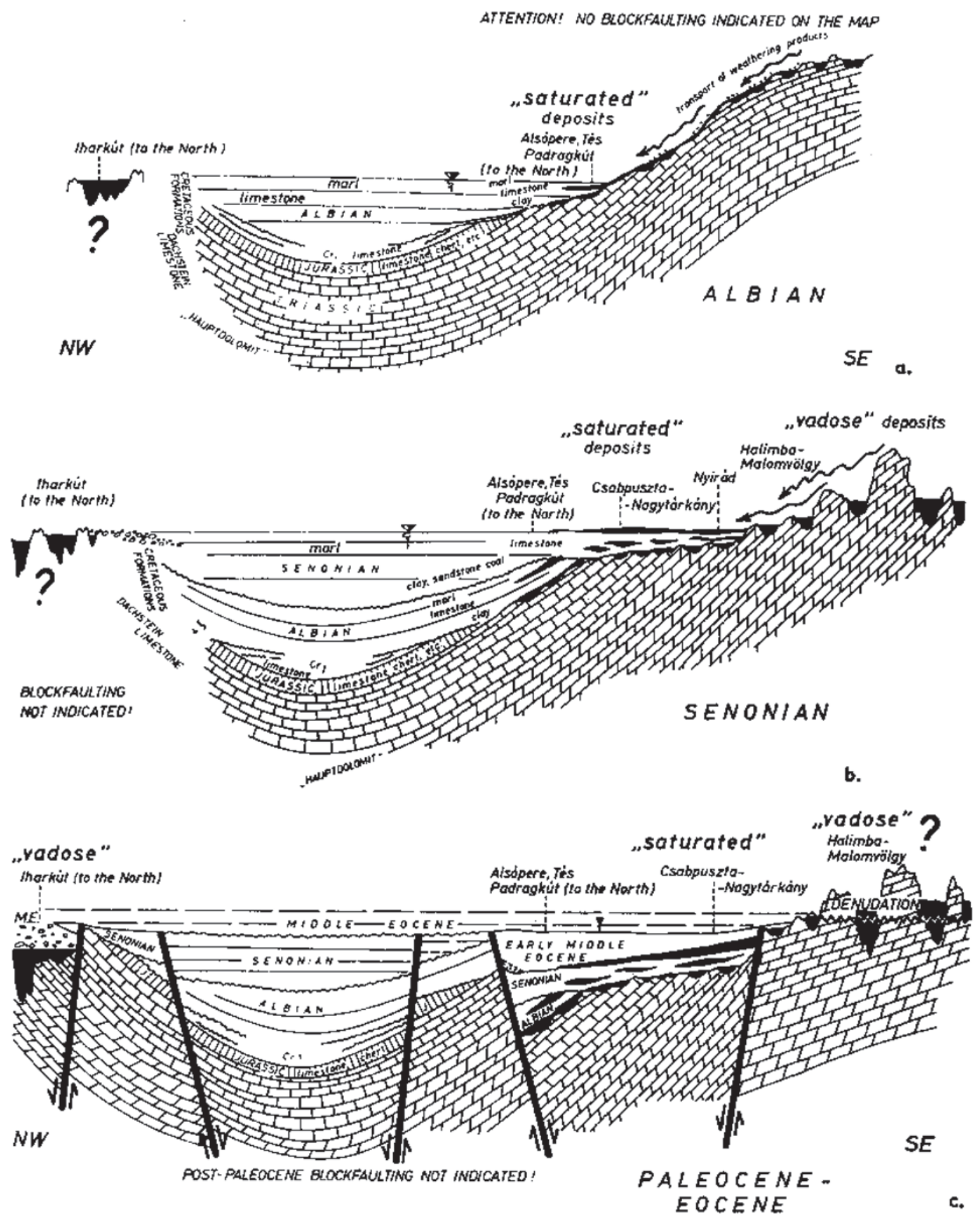

Figure 3. Idealized profiles showing the major stages of bauxite accumulation in the Transdanubian Range, reproduced from MindSZENTY (1984)

3. ábra. Idealizált szelvények a dunántúli-középhegységi bauxitképzódés fontosabb idôszakjaira vonatkozóan, MINDSZENTY (1984) után

\section{Palinspastic position of the NCA relative to the TR during bauxite deposition}

There is general agreement that Eo-Alpine Cretaceous thrusting and nappe formation in the NCA was transpressive (e.g. LINZER et al. 1995), and this is expressed by the closely spaced NW-striking dextral tear faults crosscutting the thrust sheets (Figure 1), but not the thrusts themselves (e.g. EISBACHER \& BRANDNER 1996). The style of deformation was classified as "thrust-dominated transpression" by ORTNER et al. (2016).
The nature and extent of Eo-Alpine thrusting was and, it seems like, still debated by some in the case of the TR (for a discussion, see TARI \& HORVÁTH 2010). In this work, we build on our own work (TARI 1994) describing the TR as the most internal and structurally highest segment of the EoAlpine nappe system. The structural fabric of the NCA and TR share the same primary elements (e.g. throughgoing NW-striking dextral strike-slip faults). However, these features are not nearly as well-defined in the subsurface of the TR as in the NCA, mostly because of the present-day low-relief terrain with overall poor outcrop conditions. 
Therefore the exact age of these prominent strike-slip faults is long debated in the Hungarian literature. Interpretations range from assuming an entirely Miocene period for their activity to considering a Cretaceous inception and Miocene reactivation of these features (TARI 1991, 1994; SASVÁRI et al. 2007; CSICSEK \& FODOR 2016; FODOR et al. 2017).

Regardless, as LINZER \& TARI (2012) showed, the NCA of Austria and the TR of Hungary were much closer to each other geographically during the Late Cretaceous (Figure 4) after most of the subsequent deformations responsible for their apparent present-day separation (Figure 1) are palinspastically restored. Admittedly, this cartoonish map-view restoration ignores the complex post-Santonian rotations documented in the NCA and the TR by palaeomagnetic declination anomalies (e.g. MAURITSCH \& BECKE 1987, MÁrton et al. 2000, Márton \& Fodor 2003, Pueyo et al. 2007).

If one accepts the simple model shown in Figure 4, then the differences between the Austrian and Hungarian Cretaceous bauxites, systematically described for the first time by MindSZENTY et al. (1987), may be explained in a preliminary, interpretative manner, subject to more work. The discussion here follows the same order as in the previous section:

a) The classic Gosau basins were forming closer to the leading of the Alpine orogen (Figure 5) in a wedgetop position on top of the Eo-Alpine foreland fold-and-thrust belt related to the subduction of the Alpine Tethys. The laterally variable, but pronounced subsidence in these Gosau basins were either controlled by subduction tectonic erosion (WAGREICH 1995), subduction roll-back (FroItZHEIM et al. 1997) or extensional collapse (WILLINGSHOFER et al. 1999). In contrast, the upper part of the classic Gosau basin fill finds its age equivalent in the Senonian basin of the TR, some $100 \mathrm{~km}$ southward from the Gosau basins in the NCA (Figure 4). However, the Senonian basin of the TR might have been either deposited in a different part of the same basin system or simply formed as a part of another basin. Using the recent overview forearc basins by NODA (2016) one could speculate that the extensional Gosau basins developed in the central segment of a compressional accretionary type orogene whereas the Senonian of the TR corresponded to the internal part of a forearc basin with more gradual subsidence (Figures $4 \& 5$ ). We consider the exact geodynamic context of these Senonian flexural-type basins still poorly understood at present.

b) The contrast in the facies variations in the Senonian cover of the bauxites could also be attributed to the relative tectonic positions of the classical Gosau basins versus the Senonian of the TR (Figures $4 \& 5$ ). The numerous Gosau basins were rapidly subsiding in somewhat isolated basin fragments in a generally deeper water setting (Figure 5). In

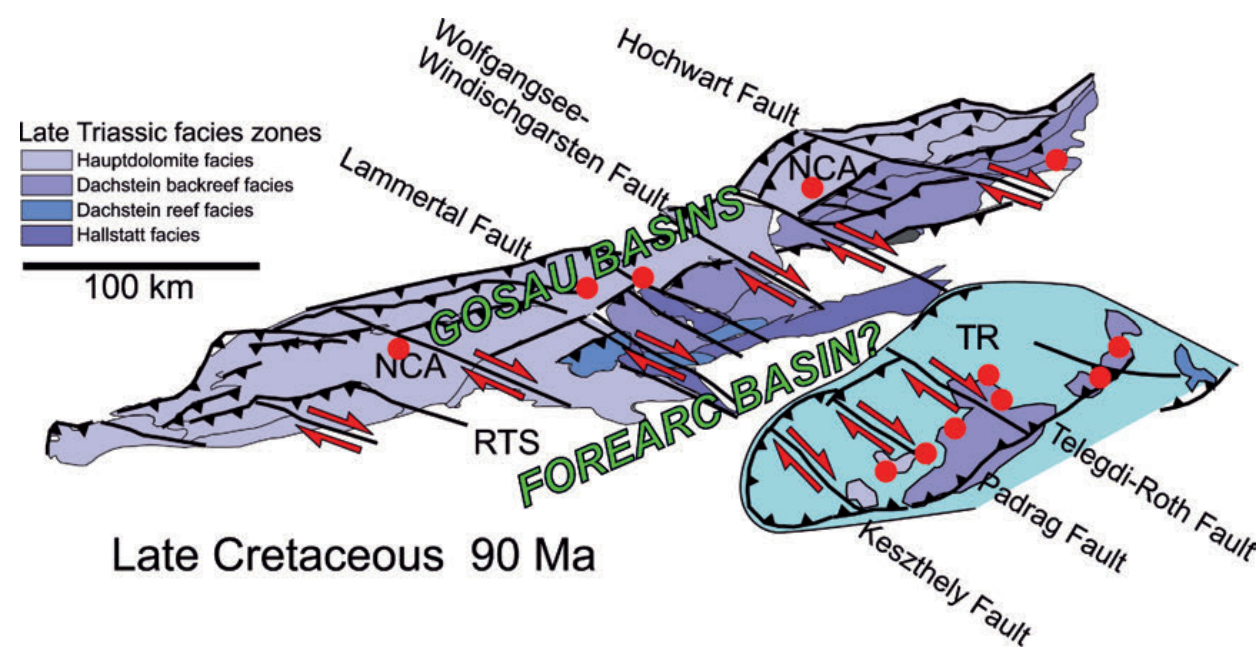

Figure 4. Cartoonish summary of Late Cretaceous structural elements and the relative positions of the Northern Calcareous Alps (NCA) and the Transdanubian Range (TR), adapted from LiNZER \& TARI (2012)

Note that the classic Alpine Late Triassic lithofacies units cannot be easily correlated with those of the TCR (János Haas, personal communication, 2017). This cartoonish map-view restoration admittedly ignores the complex post-Santonian rotations documented in both the NCA and the TR by palaeomagnetic declination anomalies (e.g. Mauritsch \& Becke 1987, Márton et al. 2000, Márton \& Fodor 2003, Pueyo et al., 2007). We believe that the right lateral Cretaceous strike-slip faults of the NCA may be correlated with those of the TR. For example, the Wolfgangsee-Windischgarsten Fault in the NCA may correspond to the Telegdi-Roth Fault in the TR. The approximate positions of the Austrian and Hungarian bauxites shown in Figure 1 are also indicated here as red dots. Note the proximity of these bauxite occurrences relative to their present-day separation from each other (cf. Figure 1). RTS = Radstadt Thrust System

4. ábra. Vázlatos összefoglalás az Északi-Mészkö-Alpok (NCA) és a Dunántúli-középhegység (TR) késó-kréta szerkezeti elemeire vonatkozóan, LINZER \& TARI (2012) után

Figyelemreméltó, hogy az NCA klasszikus alpi késö-triász litofácies zónáit nem könnyü korrelálni a TCR hasonló kifejlódéseivel (HAAS János, személyes közlés, 2017). Ez a vázlatos térképi rekonstrukció beismerten figyelmen kivül hagyja a komplex posztszenon forgásokat amiket mind az NCA és mind a TR esetében paleomágneses deklinációs anomáliák jeleznek (pl. MAURITSCH \& BECKE 1987, MÁRTON et al. 2000, MÁRTON \& FODOR 2003, PUEYO et al. 2007). Mi úgy gondoljuk, hogy az NCA kréta korújobbos elmozdulásai valószínüleg korrelálhatók a TR hasonló haránttöréseivel. Például, az NCA Wolfgangsee-Windischgarsten törése megfelelhet a TCR Telegdi-Roth törésének. Az osztrák és magyar bauxitok hozzávetöleges elhelyezését, hasonlóan az első ábrához, itt is piros pontok mutatják. Figyelemreméltó a bauxitok egymáshoz közeli viszonya a mai nagy távolság dacára (lásd 1. ábra). RTS-Radstadti feltolódási rendszer 


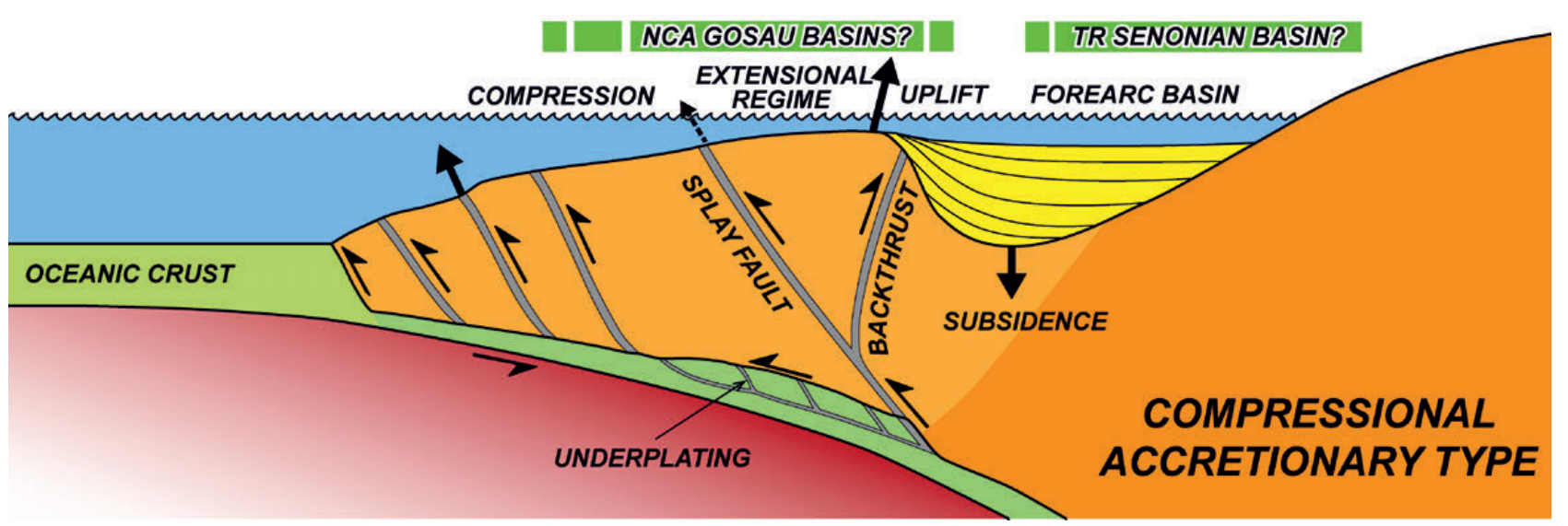

Figure 5. Summary of the main structural elements of a compressional accretionary arc (NoDA 2016). The possible positions of the classic Gosau Basins of the NCA versus the Hungarian Senonian basin on the NW flank of the TR are tentatively shown. For a corresponding speculative map-view interpretation, see Figure 4

5. ábra. Egy kompressziós akkreciós iv alapvetô szerkezeti elemeinek az összefoglalása, NodA (2016) után. A klasszikus NCA Gosau medencék és a Dunántúliközéphegység ÉNy-i szárnyán elhelyezkedö magyar senon medence lehetséges pozícióját zöld színnel kiemeltük. A regionális szelvényhez tartozó spekulativ térképi értelmezést a 4. ábra mutatja

contrast, the Senonian of the TR was clearly one single basin despite the initial separation at the base due to inherited palaeotopography (HAAs 1999) with lower subsidence rate and less water depth (Figure 5).

c) Bauxites in the Northern Calcareous Alps were covered already in the Turonian (SIEGL-FARKAS \& WAGREICH 1996) whereas the bauxitic karst terrain in the TR has remained exposed until the early Santonian (e.g. MindSZENTY et al. 1984). The prolonged period of subaerial exposure is the primary reason for the more advanced alteration observed in the Hungarian bauxites.

d) As MindSZENTY et al. (1987) already pointed out, the post-early Senonian Alpine compressional deformations and deep burial affected the Austrian bauxites much more than their age equivalent Hungarian counterparts. The more severe compaction found in the NCA bauxites is primarily due to the post-depositional structural evolution of the NCA versus the TR (Figure 1).

e) Obducted ophiolites could have been the source for the chromium spinel grains in the Gosau basins of the NCA (FAuPL et al. 1987). The Penninic ophiolites incorporated into the external part of the accretionary prism could have easily contributed laterally or downdip to the sediment fill of the Gosau basins. However, given their position, they could not have been the provenance area for the forearc basin located updip (Figure 5).

Heavy mineral studies (PoBER \& FAUPL 1988, WAGReich 1988, FAupl \& WAGREICH 1992) showed that the Turonian to Lower Santonian clastic sediments deposited in the "internal" Gosau basins were predominantly of local origin derived mainly from Permian to Triassic formations in the surroundings. Heavy mineral analysis of the lower part of the Senonian in the TR (Ajkai és a Csehbányai Formations) suggested that the chromespinels were derived from alkaline tholeitic rocks (ÁRgYelán \& HORVÁtH 2002).

\section{Bauxite formation at the margin of flexural basins}

The overall geodynamic framework for the uplift, karstification, deposition and burial of the Cretaceous Austrian and Hungarian bauxites was the Eo-Alpine tectonic evolution (oblique subduction and collision) of the Tethyan realm (MiNDSZENTY et al. 1987).

Based on detailed studies of bauxites and the overlying cover formations of the TR, MindsZENTY $(1994,1999)$ and MinDSZENTY et al. (2000) suggested that the formation of the pre-Santonian bauxites are related to foreland-type flexural deformation in front of advancing Alpine thrust units. More specifically, the formation of the Albian bauxite and its immediately overlying cover was connected with the regional compression caused by the obduction of the NeoTethys whereas the Senonian bauxite and its cover sequence formed due to the regional shortening associated with the Alpine Tethys subduction (János HAAS, personal communication 2017). According to the model of BÁRDOSSY \& MindSZENTY (2013), the deposition of bauxite deposits and their sedimentary cover was triggered and enhanced by the inception of flexural subsidence of a formerly emerged and subaerially exposed palaeosurface.

Interestingly, the flexural basin formation context appears to be applicable for many other Mediterranean bauxite deposits as well, for example in the case of Mesozoic-Tertiary Apulia in Italy (MinDSZENTY et al. 1995, D’ ARGENIO \& MindSZENTY 1995).

\section{Conclusions and the need for future work}

As a semi-quantitative map-view restoration of several consecutive Alpine deformational periods brings the Northern Calcareous Alps in Austria and the Trans- 
danubian Range in Hungary unexpectedly close to each other for the early Late Cretaceous period (LINZER \&TARI 2012), the similarities and differences between the Cretaceous Austro-Alpine bauxites summarized by MindSZENTY et al. (1987) highlight the need for further analysis of these deposits. All of these bauxites were undoubtedly formed in an orogenic setting, at the margin of flexural, generally foreland-type basins (MINDSZENTY et al. 2000). The generic flexural origin of the Upper Cretaceous basins associated with the cover sequences of the bauxites in the NCA versus the TR should have a different geodynamic context within the overall Eo-Alpine orogene. Therefore more modern data and analysis are required, especially on the much less studied Austrian bauxites, to make specific interpretations as to the provenance areas, "source-tosink" aspects and the flexural origin of the basins where they were deposited.

The poorly understood difference in the geodynamic settings of the Austrian and Hungarian bauxites is ultimately responsible for the differences between them (such as porosity, extraclast composition, degree of chemical alteration, etc.) as it was already hinted by the pioneering works of Andrea MINDSZENTY in the 1980s.

\section{Acknowledgements}

The first author is most grateful to Andrea MinDSZENTY for the geologic inspiration during the last few decades starting with his student years in Budapest in the 1980s. Her ability to always "see the outcrop not only the rocks" and the desire to look beyond the local geology is contagious. The first author also appreciates the invitation by József PÁLFY to personally contribute to Prof. MINDSZENTY's $70^{\text {th }}$ birthday celebration in Budapest. Special thanks due to Orsolya SZTANó for the invitation to contribute to this special volume and for her editorial patience. Reviewers László CsonTOS, János HAAS and László FODOR provided useful and constructive comments on the first draft of this paper, their efforts are gratefully acknowledged. SzaKáll Sándor kindly confirmed the apparent lack of carnotite in the bauxites of the TR.

\section{References - Irodalom}

ÁrgYelán, G. \& Horváth, P. 2002: Heavy mineral assemblages of Senonian formations in the Transdanubian Range, Hungary. —-Acta Geologica Hungarica 45, 319-339.

BÁrdossy, G. 2013: Karst bauxites. — Developments in Economic Geology 14, Elsevier, 442 p.

BÁrdossy, G. \& Mindszenty, A. 2013: The Iharkút Bauxite. - Occasional Papers of the Geological and Geophysical Institute of Hungary $\mathbf{1}, 133 \mathrm{p}$.

CsicseK, Á. L. \& Fodor, L. 2016: Középső-triász képződmények pikkelyeződése a bakonyi Öskü környékén (Imbrication of Middle Triassic rocks near Öskü (Bakony Hills, Western Hungary). — Földtani Közlöny 146/4, 355-370.

D'Argenio, B., \& Mindszenty, A. 1987. Cretaceous bauxites in the tectonic framework of the Mediterranean. - Rend. Soc. Geol. It. 9, 257-262.

D’ARGENIO, B. \& MindSZENTY, A. 1995: Bauxites and related paleokarst: tectonic and climatic event markers at regional unconformities. - Eclogae Geologicae Helvetiae 88, 453-500.

EISBACHER, G. H. \& BRANDNER, R. 1996: Superposed fold-thrust structures and high-angle faults, Northwestern Calcareous Alps, Austria. - Eclogae Geologicae Helvetiae 89, 553-572.

Faupl, P., Pober, E., \& Wagreich, M. 1987: Facies development of the Gosau Group of the eastern parts of the Northern Calcareous Alps during the Cretaceous and Paleogene. - In: FlÜGEL, W. \& FAuPL, P. (eds): Geodynamics of the Eastern Alps. Deuticke, Vienna, 142155.

FAuPL, P. \& WAGReICH, M. 1992: Cretaceous flysch and pelagic sequences of the Eastern Alps: correlations, heavy minerals, and palaeogeographic implications. — Cretaceous Research 13, 387-403. https://doi.org/10.1016/0195-6671(92)90006-c

Fodor, L., HÉJA, G., KövéR, Sz., CsillaG, G. \& CsicseK, Á. L. 2017: Cretaceous deformation of the south-eastern Transdanubian Range Unit, and the effect of inherited Triassic-Jurassic normal faults. — Pre-conference Excursion Guide, 15th Meeting of the Central European Tectonic Studies Group (CETeG) 5-8th April 2017 Zánka, Lake Balaton Acta Mineralogica-Petrographica, Field Guide Series 32, 47-76.

Froitzheim, N., Conti, P. T. \& VAn DAALEN, M. 1997: Late Cretaceous, synorogenic, low-angle normal faulting along the Schlinig fault (Switzerland, Italy, Austria) and its significance for the tectonics of the Eastern Alps. - Tectonophysics 280, $267-293$. https://doi.org/10.1016/s0040-1951(97)00037-1

GÜNTHER, W. \& Tichy, G. 1978: Bauxitbergbau in Salzburg. - Mitt. Ges. Salzburger Landeskunde 118, 327-340, Salzburg.

Haberfelner, E. 1951: Zur Genesis der Bauxite in den Alpen und Dinariden. — Berg- u. Hüttenmänn. Mh. 96, 62-69, 7 text-figures, Wien.

HAAS, J. 1983: Senonian cycle in the Transdanubian central range. - Acta Geologica Hungarica 26, 21-40.

HAAS, J. 1999: Late Cretaceous isolated platform evolution in the Bakony Mountains (Hungary). — Geologica Carpathica 50, $241-256$.

Kelemen, P., Dunkl, I., Csillag, G., Mindszenty, A., von Eynatten, H. \& Józsa, S. 2017: Tracing multiple resedimentation on an isolated karstified plateau: The bauxite-bearing Miocene red clay of the Southern Bakony Mountains, Hungary. — Sedimentary Geology 358, 84-96. https://doi.org/10.1016/j.sedgeo.2017.07.005

KÖHLER, A. 1955: Ein Vorkommen von Carnotit im Bauxit von Unterlaussa. — Jahrb. Oberösterr. Musealvereins 100, 359-360. 
LEISS, O. 1989: Der Bauxit und die lateritisch-bauxitischen Ablagerungen der Tiefen Gosau (Turon/Coniac) in den Nördlichen Kalkalpen. —Zeitschrift Deutsch. Geol. Ges. 140, 137-150.

LinZER, H. G. \& TARI, G. 2012: Structural correlation between the Northern Calcareous Alps (Austria) and the Transdanubian Central Range (Hungary). - American Association of Petroleum Geologists Memoir 100, 249-266.

LinZER, H. G., RATSCHBACHER, L. \& FRISCH, W. 1995: Transpressional collision structures in the upper crust: the fold-thrust belt of the Northern Calcareous Alps. — Tectonophysics 242, 41-61. https://doi.org/10.1016/0040-1951(94)00152-y

MaURitsch, H. J. \& BeCKe, M. 1987: Paleomagnetic investigation in the Eastern Alps and the southern border zone. — In: FLÜGEL, W. \& FAUPL, P. (eds): Geodynamics of the Eastern Alps. Deuticke, Vienna, 282-308.

MÁRTON, E. \& FodOR, L. 2003: Tertiary paleomagnetic results and structural analysis from the Transdanubian Range (Hungary), sign for rotational disintegration of the Alcapa unit. — Tectonophysics 363, 201-224. https://doi.org/10.1016/s0040-1951(02)00672-8

Márton, E., Kuhlemann, J., Frisch, W. \& DunkL. I. 2000: Miocene rotations in the Eastern Alps — Paleomagnetic results from intramontane basin sediments. — Tectonophysics 323, 163-182. https://doi.org/10.1016/s0040-1951(00)00102-5

MindSZENTY, A. 1984: The lithology of some Hungarian bauxites: a contribution of the paleogeographic reconstruction. - Acta Geologica Academiae Scientiarum Hungaricae 27, 441-455.

Mindszenty, A. \& D’ARgenio, B. 1987: Bauxites of the Northern Calcareous Alps and the Transdanubian Central Range: a comparative estimate. - Rend. Soc. Geol. It. 9, 269-276.

Mindszenty, A., Knauer, J. \& SzAntner, F. 1984: Az iharkúti bauxit üledékföldtani jellegei és felhalmozódási körülményei. — Földtani Közlöny 114, 19-48.

Mindszenty A., D’ARgenio B. \& Bognár L. 1987: Cretaceous bauxites of Austria and Hungary: lithology and paleotectonic implications. - Travaux ICSOBA 16-17, 14-31.

Mindszenty, A., GÁl-Sólymos, K., Csordás-Tóth, A., Imre, I., Felvári, Gy., Ruttner, A. \& Böröczky, T. 1991: Extraclasts from Cretaceous/Tertiary bauxites of the Transdanubian Central Range and the Northern Calcareous Alps. Preliminary results and tentative geological interpretation. — Jubiläumsschrift 20 Jahre Geol. Zusmmenarbeit Österreich-Ungarn, Vienna, Teil I. 309345.

Mindszenty, A., D’ARgenio, B., \& Aiello, G. 1995: Lithospheric bulges recorded by regional unconformities. The case of MesozoicTertiary Apulia. — Tectonophysics 252, 137-161. https://doi.org/10.1016/0040-1951(95)00091-7

Mindszenty, A., Csoma, A., TöröK, Á., Hips, K. \& HerTelendi, E. 2000: Flexura jellegú előtéri deformációhoz köthető karsztbauxit szintek a dunántúli középhegységben (Rudistid limestones, bauxites, paleokarst and geodynamics. The case of the Cretaceous of the Transdanubian Central Range). — Földtani Közlöny 131, 107-152.

Mindszenty, A., Ottner, F. \& Lobitzer, H. 2005: The bauxite occurrence of Russbach Almweg near Strobl, Upper Austria. — In: Weidinger J. T. \& SPITZBART, I. (eds): Geologie des Gmundner Bezirks. — Gmundner Geo-Studien 3, 47-50.

NodA, A. 2016: Forearc basins: Types, geometries, and relationships to subduction zone dynamics. — Geological Society of America Bulletin 128, 879-895. https://doi.org/10.1130/b31345.1

Ortner, H., Kositz, A., Willingshofer, E. \& SoKoutis, D. 2016: Geometry of growth strata in a transpressive fold belt in field and analogue model: Gosau Group at Muttekopf, Northern Calcareous Alps, Austria. — Basin Research 28, 731-751. https://doi.org/ 10.1111/bre.12129

PlÖCHINGER, B. 1960: Die Gosaumulde von Grünbach und der Neuen Welt. — Jahrbuch Geol. Bundesanstalt 104, 359-442.

POBER, E. \& FAUPL, P. 1988: The chemistry of detrital chromian spinels and its implications for the geodynamic evolution of the Eastern Alps. — Geologische Rundschau 77, 641-670. https://doi.org/10.1007/bf01830175

Pueyo, E. L., Mauritsch, H. J., Gawlick, H.-J., Scholger, R. \& Frisch, W. 2007: New evidence for block and thrust sheet rotations in the central northern Calcareous Alps deduced from two pervasive remagnetization events. - Tectonics 26, TC5011. https://doi.org/10.1029/2006tc001965

RutTnER, A. 1970: Die Bauxitvorkommen der Oberkreide in den Ostalpen und deren paläogeographische Bedeutung. —Ann. Inst. Publ. Hung. 56, 131-134.

RUTTNER, A. 1987: The Austrian bauxites. Their possible origin and their paleogeographic relevance. — Rend. Soc. Geol. It. 9, 281-286

RutTNER, A. \& Woletz, G. 1957: Die Gosau von Weißwasser bei Unterlaussa. Tektonische und mineralogische Untersuchungen. — Mitt. Geol. Ges. Wien 48 (1955), 221-256.

SAsvári, A., KIss, A. \& Csontos, L. 2007. Paleostress investigation and kinematic analysis along the Telegdi Roth Fault (Bakony Mountains, western Hungary). — Geologica Carpathica 58, 477-486.

SCHADLER, J. 1950: Ein neues Bauxit-Vorkommen in Oberösterreich (Rußbach bei Strobl am Wolfgangsee). — Verh. Geol. B.-A. (1948), 136137.

SchulZ, O. 1960: Bauxit in der Gosau-Schichten von Brandenberg (Tirol). — Berg- u Hüttenm. Mh. 12, 347-348.

SiEgL-FARKAS, Á. \& WAGREICH, M. 1996: Correlation of palyno- (spores, pollen, dinoflagellates) and calcareous nannofossil zones in the Late Cretaceous of the Northern Calcareous Alps (Austria) and the Transdanubian Central Range (Hungary). — Advances in Austrian and Hungarian Joint Geological Research, Budapest, 127-135.

SIEGL-FARKAS, Á. \& HAAS, J. 2002: Stratigraphic and sedimentological analysis of the Upper Cretaceous sequence of the Zala Basin on the basis of the investigation of the Szilvágy-33 well. - Acta Geologica Hungarica 45, 153-174.

TARI, G. 1991: Multiple Miocene block rotation in the Bakony Mountains, Transdanubian Central Range, Hungary. — Tectonophysics 199, 93-108. https://doi.org/10.1016/0040-1951(91)90120-h

TARI, G. 1994: Alpine Tectonics of the Pannonian Basin. — PhD Thesis, Rice University, Houston, Texas, $501 \mathrm{p}$.

TARI, G. \& HoRVÁTH, F. 2010: Eo-Alpine evolution of the Transdanubian Range in the nappe system of the Eastern Alps: revival of a 15 years old tectonic model. — Földtani Közlöny 140, 483-510. 
WAGREICH, M. 1988: Sedimentologie und Beckenentwicklung des tieferen Abschnittes (Santon-Untercampan) der Gosauschichtgruppe von Gosau und Russbach (Oberösterreich, Salzburg). — Jahrbuch der Geologischen Bundesanstalt 131, 663-685.

WAGREICH, M. 1995: Subduction tectonic erosion and Late Cretaceus subsidence along the northern Austroalpine margin (Eastern Alps, Austria). — Tectonophysics 242, 63-78. https://doi.org/10.1016/0040-1951(94)00151-x

Wagreich, M. \& FAUPL, P. 1994: Palaeogeography and geodynamic evolution of the Gosau Group of the northern Calcareous Alps (Late Cretaceous, Eastern Alps, Austria). — Palaeogeography, Palaeoclimatology, Palaeoecology 110, 235-254. https://doi.org/10.1016/ 0031-0182(94)90086-8

Willingshofer, E., Neubauer, F. \& Cloething, S. 1999: The significance of Gosau-Type Basins for the Late Cretaceous tectonic history of the Alpine Carpathian Belt. — Physics and Chemistry of the Earth (A) 24, 687-695. https://doi.org/10.1016/s1464-1895(99)00100-3

Kézirat beérkezett: 2017. 08. 08. 